\title{
Uncertainty in climate change impacts on basin-scale freshwater resources - preface to the special issue: the QUEST-GSI methodology and synthesis of results
}

\author{
M. C. Todd ${ }^{1}$, R. G. Taylor ${ }^{2}$, T. J. Osborn ${ }^{3}$, D. G. Kingston ${ }^{4}$, N. W. Arnell ${ }^{5}$, and S. N. Gosling ${ }^{5}$ \\ ${ }^{1}$ Department of Geography, University of Sussex, UK \\ ${ }^{2}$ Department of Geography, UCL, UK \\ ${ }^{3}$ Climate Research Unit, University of East Anglia, UK \\ ${ }^{4}$ Department of Geography, University of Otago, New Zealand \\ ${ }^{5}$ Walker Institute for Climate System Research, University of Reading, UK
}

Received: 23 July 2010 - Published in Hydrol. Earth Syst. Sci. Discuss.: 1 October 2010

Revised: 14 February 2011 - Accepted: 8 March 2011 - Published: 24 March 2011

\begin{abstract}
This paper presents a preface to this Special Issue on the results of the QUEST-GSI (Global Scale Impacts) project on climate change impacts on catchment scale water resources. A detailed description of the unified methodology, subsequently used in all studies in this issue, is provided. The project method involved running simulations of catchmentscale hydrology using a unified set of past and future climate scenarios, to enable a consistent analysis of the climate impacts around the globe. These scenarios include "policyrelevant" prescribed warming scenarios. This is followed by a synthesis of the key findings. Overall, the studies indicate that in most basins the models project substantial changes to river flow, beyond that observed in the historical record, but that in many cases there is considerable uncertainty in the magnitude and sign of the projected changes. The implications of this for adaptation activities are discussed.
\end{abstract}

\section{Introduction}

There is a consensus that human activities, most notably emissions of greenhouse gases (GHG), have resulted in a discernable influence on global climate, and that this has been the primary driver of global warming in recent decades (Solomon et al., 2007). Anthropogenic climate change represents a considerable challenge at many levels of society.

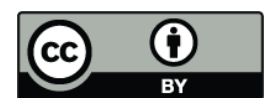

Correspondence to: M. C. Todd

(m.todd@sussex.ac.uk)
Accordingly, there have been substantial efforts to reach global agreements on GHG emission targets consistent with our scientific understanding of the relationship between GHG concentrations and dangerous climate change. However, on the basis of past GHG emissions, inertia in socioeconomic systems and limited progress in the political process (i.e. the COP-15 at Copenhagen) we must anticipate that substantial future climate change is unavoidable and that adaptation is necessary. Accordingly, decision-making bodies, including governments, are beginning to incorporate climate-related risks into decision-making processes. Given that adaptation policy tends to be made at national, regional and local levels there is a need for climate change impact assessment at these scales.

For many parts of the world climate change will be most keenly expressed through changes to freshwater availability. Dependence on water resources is such that the water sector intersects with numerous other sectors including energy generation, agriculture, fisheries, health and industry, as well as influencing ecosystem services beyond water supply. For much of the world the availability of adequate water already poses a significant challenge to development and environmental sustainability. In recognition of these challenges there have been numerous international initiatives to address the issues associated with freshwater resources. These include the UN's Agenda 21, Millennium Development Goals, Millennium Ecosystem Assessment, and World Water Development Report and the World Water Fora. Climate change is expected to be an important constraint on water availability in the future.

Published by Copernicus Publications on behalf of the European Geosciences Union. 
Changes in the distribution of river flows and groundwater recharge over space and time are determined, in part, by changes in temperature, evaporation and, crucially, precipitation. There is considerable evidence that the global hydrological cycle has already responded to the observed warming over recent decades (Trenberth et al., 2007; Bates et al., 2008), through increased atmospheric water vapour content, changing patterns of precipitation, including extremes, reduced snow and ice cover and changes to soil moisture and runoff. Climate models suggest further substantial changes to the hydrological cycle in the future under scenarios of GHG emissions. Indeed there is considerable confidence in the large-scale global pattern of projected changes to precipitation, the key driver of the terrestrial water cycle, in a warmer world. This can be characterised by the condition of "wet get wetter and dry get drier" such that the humid deep tropics and mid-latitudes will experience increased rainfall and the dry subtropics reduced rainfall (Figure 10.12 from Meehl et al., 2007). That this is a robust and physically plausible thermodynamic response to global warming has been demonstrated by Held and Soden (2006) and Seager et al. (2009), amongst others. A warmer world results in increase in specific humidly through the Clausius-Clayperon relation. The general circulation drives water vapour transport and the resulting structure of zones of convergence (wet) and divergence (dry). Increased humidity in a warmer world causes an enhancement of this structure such that wet regions become wetter and dry regions become drier. This pattern is reproduced in many climate models.

However, in most parts of the world the detailed regional and seasonal pattern of projected change for a given radiative forcing is highly variable between models (Christensen et al., 2007). This is a result of differences between model representation of various processes, notably the regional mean and transient circulation, moist convective processes, landatmosphere feedbacks and aerosol effects. This uncertainty at the all important regional and local scales has profound implications for decision making regarding adaptive responses.

The IPCC AR4 WGII critically assessed thousands of recent publications on different aspects of climate change impacts, adaptation and vulnerabilities. Within the water sector most studies use global or basin scale hydrological models driven with changes in precipitation and temperature from Global Climate Models (GCMs), typically downscaled using statistical or dynamical models. From these studies, it emerges that projected changes to river runoff have a similar pattern to that of precipitation from the driving GCMs except that the balance of changes to precipitation and increasing temperatures (i.e. P-ET) means that a greater proportion of land areas will experience reduced runoff (Fig. 1b, from Milly et al., 2005). Moreover, river systems with substantial seasonal snow/ice contributions are likely to experience reduced storage and associated seasonal regime changes. In addition, there is evidence that hydrological extremes may become more likely in the future (Allen and Ingram, 2002;
Alexander et al., 2006; Meehl et al., 2007). It is abundantly clear from these studies that climate change has the potential to substantially impact water resources.

The relationship between climate and water resources does not exist in isolation but is strongly influenced by socioeconomic and other environmental conditions. Various human activities influence available water resources, most notably agriculture, land use, construction, water pollution and water management and river regulation. At the same time, water use is highly variable and largely determined by population, levels of development and access, through a complex web of socio-economic and political processes. Achieving water security remains a challenge in many parts of the world, and may be a pre-requisite for development and economic growth. Achieving this requires substantial investment which must take into account environmental sustainability and social inclusion and equity (Grey and Sadoff, 2007). Climate change affects the function and operation of existing water infrastructure - including hydropower, structural flood defences, drainage and irrigation systems as well as water management practices. As current water management practices may not be robust enough to cope with the impacts of climate change, adaptive responses will be necessary. Analyses of climate and water resources should account for these human dimensions.

To date, there have been very few coordinated attempts to consistently estimate and summarise the geographic variability in global-scale impacts of climate change: the vast majority of impact assessments have been local in focus and have used a variety of scenarios and assumptions as illustrated, for example, in the global impact reviews of Hitz and Smith (2004) and Warren (2006). Some exceptions include the DEFRA Fast Track study (Arnell, 2004a; Arnell et al., 2002; Levy et al., 2004; Nicholls, 2004; Parry et al., 2004; Van Lieshout et al., 2004) and the EU-funded ATEAM project (Schroeter et al., 2005). Some integrated modelling studies that include assessments of impacts have used geographically-explicit impacts models (e.g. Toth et al., 2003; Leemans and Eickhout, 2004), but most such studies have used reduced-form impact models, which do not capture all the details and subtleties of geographically-varying impacts (e.g. Tol, 2005; Mastrandrea and Schneider, 2004).

The limitations in previous studies make it difficult to assess impacts at the global scale and to compare impacts for different socio-economic and climate futures. Furthermore it makes it difficult to assess the effectiveness of proposed policy measures to reduce greenhouse gas emissions and, thus, the impacts of climate change. The QUESTGSI (Global Scale Impacts, http://www.met.reading.ac.uk/ research/quest-gsi/) project is an integrated, multi-sector and multi-scale analysis of climate change impacts, utilising a unified set of climate drivers and socio-economic data, to allow a consistent analysis of impacts, associated uncertainty and vulnerability. In this special issue we report only on the results of the analysis to quantify climate change impacts on 
water resources to inform mitigation and adaptation policy in the water sector. The results of the analysis in QUEST-GSI in other sectors, including food and health will be reported elsewhere. Notwithstanding the needs for an integrated global scale analysis, the human response to climate change impacts on the water sector will generally be conducted at the catchment scale. As such, impacts and responses will be highly variable and depend upon local climate and socio-economic conditions. Clearly global-scale analyses cannot hope to consider the complex local scale context of climate-society interactions. However, to date, most basin-scale studies have been local in focus, using a range of scenarios, methods and approaches. In recognition of this, QUEST-GSI incorporated a coordinated, systematic and extensive analysis of climate impacts on water resources at the catchment scale, to complement the global analysis. A network of river basins was established in order to consider a range of climate and socioeconomic conditions and water resources contexts. This informal "network of opportunity" provides one of the first systematic, multi-basin experiments, global in extent and using a consistent suite of climate drivers. In addition, we compare uncertainty in basin-scale experiments with output from a global hydrological model (Gosling et al., 2011). Detailed catchment studies provide a useful forum to assess the science of climate change impacts (e.g. uncertainty in climate and hydrological models) in the context of locally specific developmental concerns, adaptive responses, vulnerability drivers, stakeholder relationships and risk evaluations all of which strongly influence the actual outcome of climate change on water resource. It also allows validation at the catchment scale in predictions of the global-scale hydrological impact models. Finally our network of basins around the world provides a forum for exchange of ideas on climate, hydrology and water management in the context of climate change.

The aims of this paper are to provide (i) a preface to this Special Issue (Sect. 1) (ii) a detailed description of the methodology used to develop the unified set of policyrelevant climate scenarios (Sect. 2) (iii) a synthesis of the main findings of the individual river basin studies (Sect. 3).

\section{QUEST-GSI project methodology}

The QUEST-GSI project methodology is similar to previous climate impact studies in that impact models (in this case hydrological models) are driven by an ensemble of future climate scenarios to provide estimates of future climate change impacts on water, and the associated uncertainty. However the method adopted has a number of features that represent an advance on many previous studies: (i) a global and river basin scale analysis using a consistent set of climate projections (ii) use of prescribed warming scenarios to inform mitigation policy and (iii) consideration of adaptation and vulnerability in study basins.

\subsection{The network of river catchments}

QUEST-GSI coordinated a network of river catchments from around the world. This international network was created to allow a consistent quantitative analysis of climate change impacts but also to provide a framework with which to share experience on the processes of adaptation to climate change and other drivers of change. The QUEST-GSI catchments are global in coverage and feature strong contrasts in spatial scale as well as climatic and developmental conditions (Fig. 1, Table 1). Basins were selected where international researchers had already established locally calibrated, distributed catchment-scale hydrological models (CHMs) derived from previous and on-going research projects. The CHMs are described in detail in each of the papers in this issue. The CHMs simulate water resource impacts based on a more explicit representation of catchment water resources (e.g., soil water, groundwater, snow/ice, river channel losses) than that available from global hydrological models. All basin partners were provided with a consistent set of historical climate and future climate data for their analyses (see Sect. 2.2). All the hydrological models had already been calibrated, typically using local gauge networks. In each case the basin model was re-calibrated for use with the gridded historical CRU TS3.0 data (Mitchell and Jones, 2005) for the period 1961-1990. This process is described in each of the individual papers. In addition to the CHMs, six of the nine individual catchments were analysed using a global hydrological model MacPDM (Gosling and Arnell, 2011; Gosling et al., 2010; Arnell, 2003a; 2004a). MacPDM simulates the terrestrial water cycle and resource availability on a gridded basis across the world at 0.5 degree resolution. The water budget is simulated independently for each grid cell and monthly river runoff is simply aggregated for all grid cells within the boundaries of the major river basins of the world.

\subsection{Climate data and scenarios}

\subsubsection{Historical data}

Monthly observations of precipitation, mean, minimum and maximum temperature, vapour pressure cloud cover, and number of rain days, were obtained from the 0.5 degree gridded CRU TS3.0 dataset. All grid cells whose centre is located within the basin boundaries were extracted. These monthly fields were used for two purposes: (i) as the baseline data from use in the climate change scenarios (Sect. 2.3); and (ii) to provide driving fields for hydrological models for the baseline period.

\subsubsection{Climate scenarios}

The QUEST-GSI integrated multi-sectoral analysis requires a unified set of future climate scenarios that (i) characterise as fully as possible the associated uncertainties, (ii) allow the construction of generalised relationships between global 

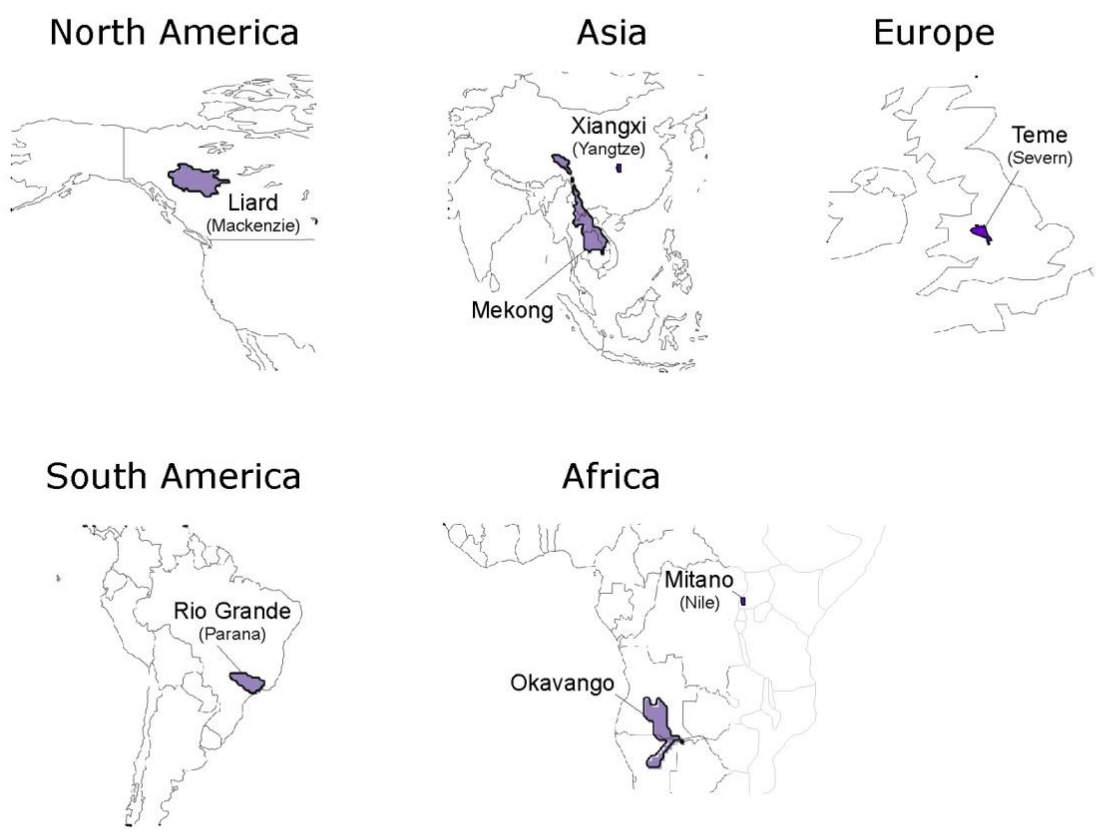

Fig. 1. Maps of the study river catchments.

climate forcing and local impact, and (iii) have space/time scales appropriate to drive impact models. The first requirement is met firstly by sampling the uncertainty associated with climate model structural uncertainty by creating scenarios from seven "priority" GCMs, under specified emissions scenarios using output from the GCM experiments from the World Climate Research Programme (WCRP) Coupled Model Intercomparison Project phase 3 (CMIP3) multimodel dataset. The CMIP3 model dataset formed input to the Intergovernmental Panel on Climate Change (IPCC) Fourth Assessment Report (AR4) (Solomon et al., 2007). Using a subset of the CMIP3 models in this study was necessary given the logistical difficulties of running ensemble experiments with the various catchment hydrological models. Our priority was to ensure a consistent set of climate forcings for a unified climate impact assessment across the catchments. Nevertheless, the priority subset of the CMIP3/IPCC-AR4 GCMs used in this study was carefully selected on the basis of (i) a subjective evaluation of model quality and (ii) the use of the model (or its predecessors) in previous impact assessments. The priority subset was checked to ensure that it spanned the range of different changes in precipitation. The models selected are the CCCMA-CGCM31, CSIRO-Mk3.0, IPSL-CM4, ECHAM5/MPI, NCAR-CCSM30, UKMO-HadGEM1 and HadCM3. A description of the model and experiments can be found online ${ }^{1}$. Secondly, we sample a number of contrasting

\footnotetext{
${ }^{1}$ http://www-pcmdi.llnl.gov/ipcc/model_documentation/ ipcc_model_documentation.php
}

GHG emission scenarios, to represent a range of possible future development pathways. We have not considered uncertainty associated with model internal variability (often represented by initial condition ensembles of individual climate models) as this source of uncertainty is believed to be small relative to the others, especially over climatological periods considered here.

The second and third requirements are met by deriving spatial patterns of climate change using the climate impact interface software "ClimGen" (Osborne, 2009), available from http://www.cru.uea.ac.uk/ timo/climgen/. ClimGen creates climate scenarios through a pattern scaling approach in which climate change patterns as simulated by a suite of GCMs are applied to an observed $0.5^{\circ} \times 0.5^{\circ}$ baseline climatology, namely the CRU TS3.0 data, the most comprehensive historical climate dataset available at high resolution. A fundamental assumption of ClimGen is that the spatial and temporal pattern of change in climate as simulated by a GCM with a given change in global average temperature can be linearly rescaled to represent the pattern of change in climate associated with a different global temperature change (the pattern-scaling assumption). The pattern-scaling approach assumes that each climate variable responds linearly to changing global mean annual temperature. Whilst this has been shown to be a reasonable assumption for moderate amounts of climate change 15 (Mitchell, 2003), it may not hold for high changes, and is unlikely to hold where the rate of temperature change slows or even reverses. ClimGen can provide scenarios down to a spatial resolution of $0.5^{\circ} \times 0.5^{\circ}$, through linear interpolation of the coarse resolution GCM 
Table 1. Summary of basin characteristics and models employed in the QUEST-GSI study.

\begin{tabular}{|c|c|c|c|c|c|}
\hline River Basin & Area $\left(\mathrm{km}^{2}\right)$ & Hydrological model & Key water uses & Climatic zone(s) & Lead \\
\hline $\begin{array}{l}\text { Mekong } \\
\text { southeast Asia }\end{array}$ & 569410 & $\begin{array}{l}\text { SLURP (v. 12.7) } \\
\text { semi-distributed } \\
13 \text { sub-basins } \\
\text { Kite }(1995)\end{array}$ & $\begin{array}{l}\text { agriculture } \\
\text { hydro-electric } \\
\text { power } \\
\text { public water } \\
\text { supply }\end{array}$ & $\begin{array}{l}\text { high-altitude } \\
\text { sub-tropical, } \\
\text { humid tropical }\end{array}$ & 1 \\
\hline $\begin{array}{l}\text { Liard } \\
\text { (MacKenzie tributary) } \\
\text { Canada }\end{array}$ & 275000 & $\begin{array}{l}\text { SLURP (v. 12.2) } \\
\text { semi-distributed } \\
35 \text { sub-basins } \\
\text { Kite et al. (1994) }\end{array}$ & $\begin{array}{l}\text { environmental } \\
\text { flows }\end{array}$ & $\begin{array}{l}\text { Arctic and } \\
\text { sub-Arctic }\end{array}$ & 2 \\
\hline $\begin{array}{l}\text { Okavango } \\
\text { southern Africa }\end{array}$ & 226256 & $\begin{array}{l}\text { Pitman } \\
\text { semi-distributed } \\
14 \text { sub-basins } \\
\text { Hughes et al. (2006) }\end{array}$ & $\begin{array}{l}\text { environmental } \\
\text { flows }\end{array}$ & $\begin{array}{l}\text { humid and } \\
\text { semi-arid } \\
\text { tropical }\end{array}$ & 3 \\
\hline $\begin{array}{l}\text { Rio Grande } \\
\text { (Parana tributary) } \\
\text { Brazil }\end{array}$ & 145000 & $\begin{array}{l}\text { MGB-IPH (VIC) } \\
\text { distributed } \\
\text { Collischonn et } \\
\text { al. (2007) }\end{array}$ & $\begin{array}{l}\text { hydro-electric } \\
\text { power }\end{array}$ & humid tropical & 4 \\
\hline $\begin{array}{l}\text { Xiangxi } \\
\text { (Yangzte tributary) China }\end{array}$ & 3099 & $\begin{array}{l}\text { AV-SWAT-X } 2005 \\
\text { semi-distributed } \\
\text { Arnold et al. (1998) }\end{array}$ & $\begin{array}{l}\text { agriculture } \\
\text { hydro-electric } \\
\text { power }\end{array}$ & $\begin{array}{l}\text { humid } \\
\text { sub-tropical }\end{array}$ & 5 \\
\hline $\begin{array}{l}\text { Huangfuchuan, (Yellow } \\
\text { tributary) China }\end{array}$ & 3240 & $\begin{array}{l}\text { AV-SWAT-X } 2005 \\
\text { semi-distributed } \\
\text { Arnold et al. (1998) }\end{array}$ & agriculture & $\begin{array}{l}\text { humid } \\
\text { mid-latitude }\end{array}$ & 5 \\
\hline $\begin{array}{l}\text { Mitano River } \\
\text { (Nile tributary) } \\
\text { Uganda }\end{array}$ & 2098 & $\begin{array}{l}\text { AV-SWAT-X } 2005 \\
\text { semi-distributed } \\
\text { Arnold et al. (1998) }\end{array}$ & agriculture & humid tropical & 1 \\
\hline $\begin{array}{l}\text { Harper's Brook } \\
\text { (Nene tributary), Greta, } \\
\text { Lambourn, Medway, } \\
\text { Teme and Eden }\end{array}$ & $74-1134$ & $\begin{array}{l}\text { Cat-PDM } \\
\text { distributed } \\
\text { Arnell (2003b, 2004b) }\end{array}$ & & $\begin{array}{l}\text { humid, } \\
\text { temperate }\end{array}$ & 6 \\
\hline
\end{tabular}

1: University College London, UK (Kingston and Taylor, 2010); 2: McMaster University, Canada (Thorne, 2010); 3: Rhodes University, South Africa (Hughes et al., 2010); 4: Universidade Federal do Rio Grande do Sul and Instituto de Pesquisas Hidráulicas, Brazil (Nobrega et al., 2011); 5: National Climate Centre, China (Xu and Taylor, 2011); 6: Reading University, UK (Arnell, 2010)

climate change patterns, and uses a range of different scaling methods to construct scenarios for changes in not only the mean but also the year-to-year variability in climate.

The method is described as follows. First, for each climate model the global mean temperature change $(\Delta T)$ and the spatial pattern of climate change in a given variable, for each month (January-December) are obtained from the change in $30 \mathrm{yr}$ mean at the end of the 21st century (2070-2099) relative to the 1960-1990 reference periods. The future climate fields are obtained from the GCM run forced with the IPCC SRES A2 scenario (and validated by comparing rescaled patterns with changes simulated by the same model under A1b emissions). By dividing the climate change in a particular variable at each grid cell by $\Delta T$ the "standardised" pattern of climate change in that variable per unit global mean temperature increase is defined. This procedure is referred to as "pattern scaling" and allows calculation of the spatial pattern of climate change in any variable, associated with any given global mean temperature change, assuming a linear dependence of change on $\Delta T$. These standardised climate change patterns are calculated separately for each month to preserve the seasonal information, and are all interpolated statistically onto the $0.5^{\circ} \times 0.5^{\circ}$ global grid. Within ClimGen these patterns are used to create gridded fields of monthly data with which to drive the hydrological models. In essence, the change pattern is used to perturb a historical dataset to ensure minimal bias with respect to observations, a necessary condition for running impact models calibrated with respect 
to historical observations. The precise methodology of the perturbation depends first on the variable of interest and on whether the scenario is a "prescribed warming" or transient SRES scenario. In essence though, the climate change field is "added" to the historical data from CRU TS3.0. ClimGen (version 1.00) currently generates projected fields for eight climate variables, (namely monthly precipitation, number of wet days, mean, minimum and maximum temperature, diurnal temperature range, vapour pressure and cloud cover), using slight variations in this procedure described below. In total, more than 90 scenarios of future climate were generated including 10 increments of $\Delta T$ and 3 SRES scenarios (A2, B2, and A1B) for each of the 7 GCM patterns. These data were then used to drive the hydrological impact model in each study catchment. Using ClimGen, these climate scenarios for hydrologically-relevant variables were created at a $0.5^{\circ} \times 0.5^{\circ}$ resolution suitable to drive the hydrological models.

\section{Temperature, vapour pressure and cloud cover}

Scenarios for mean, minimum and maximum temperature vapour pressure and cloud cover are all constructed in the same way. As shown in Eq. (1), a time series, $X$ spanning the period $y=20 \mathrm{xx}$ to $20 \mathrm{yy}$ is created by scaling the appropriate GCM-derived change in mean monthly climate by the temperature change, $t$, in year yr, (3rd term on right hand side of Eq. 1) and adding the change to the observed monthly climate time series (first two terms on right hand side of Eq. 1) where the subscripts define variable $(v)$, GCM pattern $(g)$, emissions scenario $(s)$, grid box $(i)$, year $(\mathrm{yr})$ and month $(\mathrm{m})$. $\bar{o}_{v i \mathrm{~m}}$ is the mean monthly climate; $o_{v i \mathrm{yrm}}^{\prime}$ is the time series of interannual anomalies; $p_{v g s i m}$ is the absolute change in mean monthly climate and $t_{g s y r}$ is change in global temperature in year yr.

$X_{v g s i \mathrm{yrm}}=\bar{o}_{v i \mathrm{~m}}+o_{v i \mathrm{yrm}}^{\prime}+\left(p_{v g s i \mathrm{~m}} \times t_{g s \mathrm{yr}}\right)$

Where a value falls outside the range of the physically possible, the value is corrected to the outer limit of that range. This produces perturbed monthly time series with a gradually changing mean (because the temperature change $t_{g s y r}$ is lower at the beginning of the time horizon than at the end) but unchanged inter-annual variability. As an illustration, $t_{g s y r}$ varies from 3.17 and $4.76^{\circ} \mathrm{C}$ between 2070 and 2099 under the HadCM2 A2 scenario. Note that for the prescribed warming scenarios the term $t_{g s y r}$ does not vary over time but is predefined, in $0.5^{\circ} \mathrm{C}$ intervals from +0.5 to $6.0^{\circ} \mathrm{C}$. Note that in the equations that follow the subscripts $i$, yr and $\mathrm{m}$ are defined as above and that the subscripts $v, g$ and $s$ are dropped for simplicity.

\section{Precipitation}

For precipitation and wet days, the method is the same except that $p$ in Eq. (1) is the ratio of climate change rather than the absolute change and historical data are scaled multiplicatively using the ratio. Patterns of change in precipitation, relative to 1961-1990, are calculated using Eq. (2) where $p_{b i}$ is the simulated baseline precipitation for grid cell $i, p_{f i}$ is the simulated future precipitation, and $\tilde{p}_{i \mathrm{~m}}$ is precipitation change for month $\mathrm{m}$ and grid cell $i$.

$\tilde{p}_{i \mathrm{~m}}=\ln \left(p_{f i \mathrm{~m}} \times p_{b i \mathrm{~m}}^{-1}\right)$

The rescaled future precipitation is calculated from Eq. (3) where $P_{i \text { yrm }}$ is precipitation for grid cell $i$, year yr and month $\mathrm{m}, \bar{O}_{i \mathrm{~m}}$ is the observed mean precipitation for month $\mathrm{m}$, $\tilde{O}_{i y r m}$ is the precipitation anomaly for year yr and month $\mathrm{m}$, and $t_{\mathrm{yr}}$ is temperature change for year yr.

$P_{i \mathrm{yrm}}=\bar{O}_{i \mathrm{~m}} \times \tilde{O}_{i \mathrm{yrm}} \times e^{\left(\tilde{p}_{i \mathrm{~m}} \times t_{\mathrm{yr}}\right)}$

As such, the magnitude of the mean precipitation change is an exponential function of global-mean temperature change rather than a linear function. This avoids obtaining zero precipitation in regions of decreased mean precipitation, because the rate of change decelerates as temperature increases, but it results in accelerating changes in regions of increased mean precipitation.

In addition, the year-to-year variation is altered according to GCM-derived changes in precipitation probability distributions (parameterised via the shape parameter of the gamma distribution). The difference between the gamma distribution parameters calculated over the baseline and scenario periods is standardised by global temperature change, and these standardised differences rescaled to a defined global temperature change. This perturbation in variance is applied to the monthly precipitation anomaly in Eq. (3).

\section{Number of wet-days}

GCMs do not provide realistic representations of the number of wet days (because precipitation is drizzled across a large grid cell), so changes in wet day frequency were derived from changes in precipitation. New et al. (2000) found a strong relationship in the observed climatology between mean monthly wet-day frequency and mean monthly precipitation, $a_{i \mathrm{~m}}$, (Eq. 4 ) where $\bar{W}_{i \mathrm{~m}}$ is mean monthly wet days for grid cell $i$ and month $\mathrm{m}$.

$a_{i \mathrm{~m}}=\frac{\left(\bar{W}_{i \mathrm{~m}}\right)^{2.22}}{\bar{O}_{i \mathrm{~m}}}$

Rescaled future wet day frequency is then calculated from Eq. (5) where $W_{i y r m}$ is the number of wet days for grid cell $i$, month $\mathrm{m}$ and year yr.

$W_{i \mathrm{yrm}}=\left(a_{i \mathrm{~m}} \times P_{i \mathrm{yrm}}\right)^{0.45}$

\subsection{The weather generator}

Many of the hydrological impact models require climate information at the daily scale. As ClimGen operates only 
at the monthly scale, a weather generator, described in Arnell (2003a), was applied to create daily data from monthly data. This is a stochastic model which assumes daily precipitation follows a gamma distribution, with the coefficient of variation of daily precipitation derived from analysis of available rain gauge data from within each basin. The occurrence of precipitation is described by a simple two-state Markov model with transitional probabilities fixed. The details of the daily disaggregation are not too important as daily data are rescaled to maintain the correct monthly total. Although the precise temporal pattern can be important to the hydrological response, this is not deemed to be important here given our interest in long-term, hydrological responses. Daily temperature is required for the snow component, determined by fitting a sine curve to the maximum and minimum temperatures and adding random variation around this (normally distributed with a standard deviation of $2{ }^{\circ} \mathrm{C}$ ), to allow for alternating periods of snow and rain.

\subsection{Summary of scenario generation methodology}

In this project a set of consistent climate change scenarios were created to drive catchment scale and global hydrological models over a series of test river catchments around the world. The scenarios include unique policy-relevant "prescribed warming" scenarios for different amounts of climate forcing (global temperature increase of 0 to $6^{\circ} \mathrm{C}$, in $0.5^{\circ} \mathrm{C}$ increments) for a single GCM (HadCM3) and $2^{\circ} \mathrm{C}$ rise in global mean air temperature, long considered as a threshold of dangerous climate change, for all 7 "priority" GCMs. These driving scenarios enabled researchers to (i) quantify the climate change impacts on river basin hydrology and water resources (ii) compare the magnitude of climate impacts associated with different levels of global warming (iii) assess the uncertainty associated with a given climate forcing, that arises from inter-GCM uncertainty (iv) assess the uncertainty associated with different emission scenarios.

\section{Synthesis of main findings from the basin scale studies}

Detailed results from individual river basins and a discussion of the implications are presented in the respective papers in this special issue. Here we reflect on the outcomes of the methodological approach and review key generic findings from catchment-scale analyses.

i. Overall, ClimGen software provides a simple and useful platform for the generation of globally consistent climate scenarios. ClimGen was applicable for global, regional and catchment-scale studies of the hydrological impacts of climate change, under specific GHG emission scenarios and for prescribed level of global warming. In all but one river basin recalibration of existing catchment hydrological models was successfully achieved using 0.5 degree monthly gridded, observational climate datasets.

ii. Catchment-scale hydrological impact models indicate major changes in river discharge associated with future climate changes (Figs. 2 and 3). The results here give a clear indication that changes in hydrological regimes of magnitudes unprecedented in the historical record are possible under conditions of a 2-degree rise in global mean temperature.

iii. The level of uncertainty in many regions is high such that even the sign of change is unpredictable at present (Fig. 3). This uncertainty stems mostly from inter-GCM uncertainty in precipitation projections. For three of the large basins (Mekong, Rio Grande, and Okavango) uncertainty in projections of mean river discharge under a $2{ }^{\circ} \mathrm{C}$ rise in global mean air temperature is such that there is no consensus in the magnitude or even the direction of projected change. For other catchments (the Liard and Xiangxi in the mid-high latitudes and the Loktak lake basin in Eastern India) hydrological projections under a $2{ }^{\circ} \mathrm{C}$ increase in global mean air temperature are more consistent at least in the direction of change (a projected increase in river flow). This is in line with agreement between GCMs on a wetter regime in those locations. Results from the Liard basin where snowmelt is an important component, and the Xiangxi River, indicate that whilst there is considerable uncertainty in the magnitude of projected mean-annual runoff change there is higher confidence in directional shifts of the seasonal cycle. Uncertainty can be high even for basins which lie within regions where it is believed that the climate change precipitation signal is relatively robust (Christensen et al., 2007), notably the Mitano river in East Africa (wetter) and the Okavango in southwestern Africa (drier). This highlights the problems where the study region lies close to, or straddles, the boundary between robust and uncertain climate projections.

iv. Projected impacts of climate change are relatively insensitive to hydrological model parameter uncertainty. Ensembles of hydrological model runs representing hydrological parameter uncertainty only (e.g. Kingston and Taylor, 2010, Hughes et al., 2010; Arnell, 2010; $\mathrm{Xu}$ and Taylor, 2011) introduced substantially less uncertainty than that associated with GCM structural uncertainty.

v. There is a divergence between the study catchments in the linearity of hydrological responses to the magnitude of global warming (Fig. 2). Whilst in some basins (Rio Grande, Okavango, and Xiangxi) the magnitude of hydrological impact increases fairly linearly with increasing global mean temperature rises, this is not so in others (e.g. Mitano, Liard, and Teme). In these latter basins 


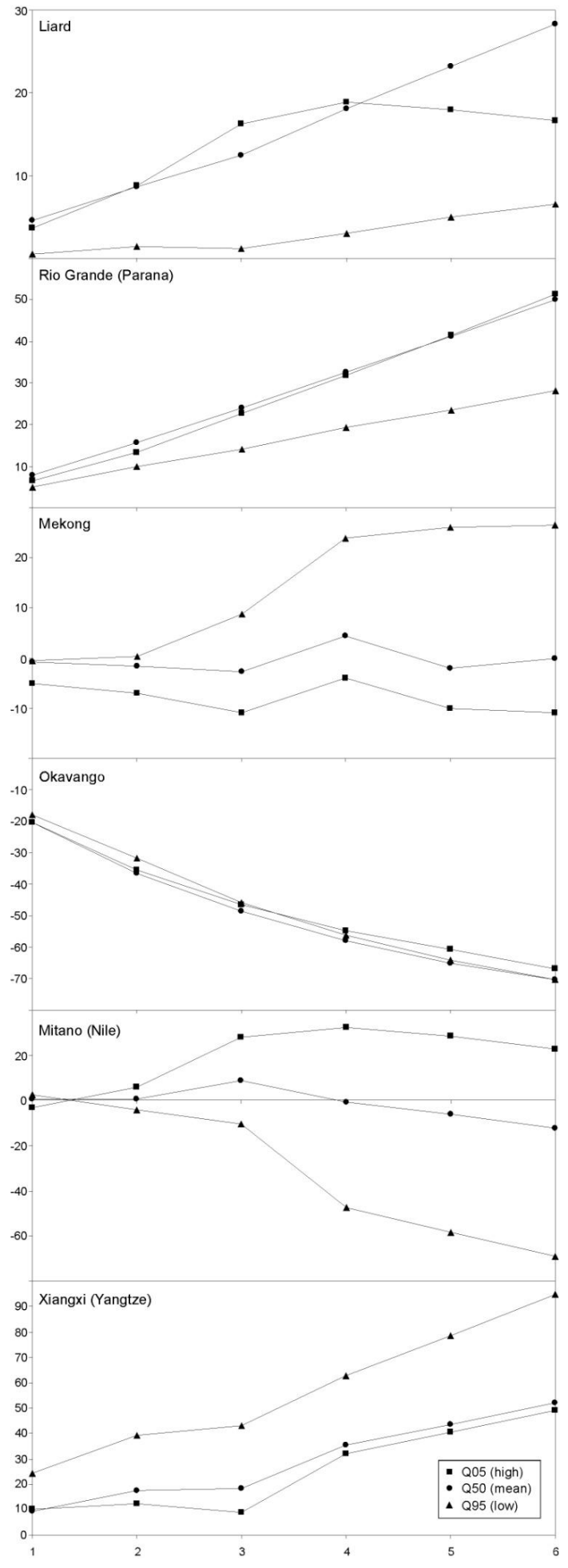

Fig. 2. Projected 30-yr change in river flow (\% change from 19611990 baseline) for the study basins as a function of global mean temperature increase, with driving climate data from the HadCM3 GCM.

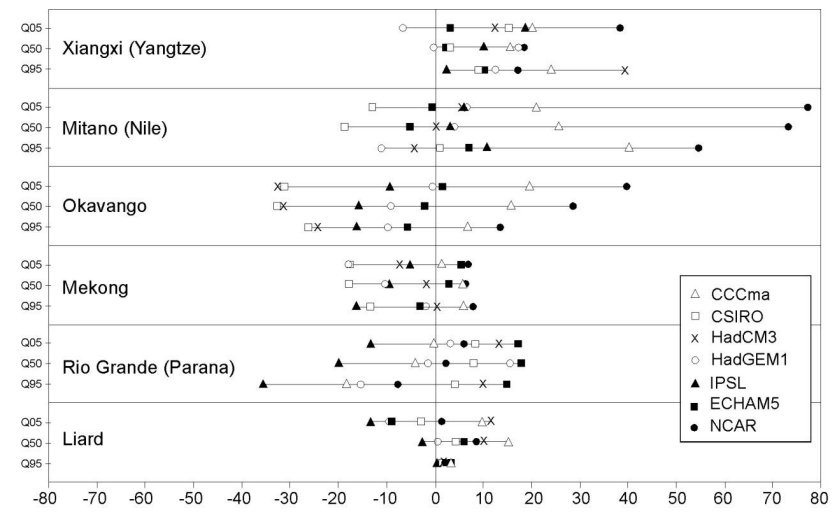

Fig. 3. Envelope of projected 30 -yr mean changes in metrics of river flow (\% difference from 1961-1990 baseline) for the study basins. For each catchment, the top, middle and bottom lines represents Q05, Q50 and Q95 flows (i.e. exceedance in \% of months over the simulated 30-yr period).

the sign of hydrological response changes sign from positive to negative at higher levels of global warming, presumably as increased ET dominates over the precipitation signal in determining the water balance.

vi. Results highlight limitations in the common use of mean river discharge as a measure of the response of hydrological systems to climate change and freshwater availability. The catchment-scale studies in this special issue show that reporting hydrological change in terms of mean river discharge, as is commonplace, can mask considerably greater changes in intra-annual (seasonal) low (Q95) and high (Q05) flows which are of fundamental importance to water management and our understanding of freshwater availability. For example, reductions in low flows can lead to acute water shortages as well as affect environmental flow requirements and dry-season water allocations; changes in high flows can impact flood risk and basin storage requirements. The implications of this for commonly used indices such as the water stress index and relative water demand are discussed by (e.g. Taylor, 2009).

vii. Differences in projected river discharge changes between Catchment Hydrological Models and the Global Hydrological Model are generally relatively small. A new feature of this QUEST-GSI study is the application of both a GHM (the MacPDM model) and a Catchment Hydrological Model (CHM) for each study basin. Differences in projected hydrological changes are generally relatively small, in comparison to the range of projections across the seven GCMs (Gosling et al., 2011). This implies that climate model structural uncertainty is greater than the uncertainty associated with the type of hydrological model applied, so it may be equally 
feasible to apply a GHM or CHM to explore catchmentscale changes in runoff with climate change from ensembles of GCM projections, despite the generalisations GHMs need to make in order to be run over the global domain.

\section{Concluding discussion}

The QUEST-GSI project provides a unified approach to climate change impacts assessment for water resources. This paper provides a summary of the methods used to generate a set of consistent climate scenarios to drive hydrological models for river basins across five continents reported in the special issue. Together, these basin studies provide an extensive assessment of uncertainty in climate change impacts on water resources at the catchment scale. The results clearly indicate that changes in hydrological regimes of magnitudes unprecedented in the historical record are possible. Critical to forecasts of freshwater availability, basin studies reveal that projected changes in low (Q95) and high (Q05) river flows can exceed that of the commonly reported mean. The level of uncertainty in many regions is, however, high such that even the sign of hydrological change is unpredictable at present. This result reinforces the need to recognise that whilst globally robust changes in the hydrological cycle may be emerging (i.e. the "wet get wetter, dry get drier" pattern of precipitation change) in many regions, at the basin scale uncertainty is the dominant characteristic.

A number of important caveats must be recognised up front, which are related to the discussion which follows. First, the project is not designed to be a comprehensive global assessment of water resources. The river basins were selected as a sample of "opportunity" and as such are indicative of various regions and human dimensions. Second, to follow the unified methodology we necessarily compromised on complexity. For logistical reasons we make no attempt at probabilistic techniques, nor of sophisticated downscaling or extreme value analysis techniques. Moreover, for these basins the shape of the probability distribution remains relative stable between the GCM experiments. However, it should be noted that the method adopted here does not account for projected changes in the intensity of rainfall at submonthly timescales. As such, our projections almost certainly under-represent uncertainty in climate change impacts. It is important to bear this point in mind in the following discussion.

Quantitative projections of climate change impacts on catchment scale water budgets provide the potential to inform water management decision making. The degree of social necessity in such decisions clearly varies between basins studied here. For example, there is far less need to manage water resources in the Liard River compared to the Rio Grande. In addition, the degree and nature of water resource development in a particular catchment determines the time scales over which planning decisions are likely to be made. In particular, those basins with hydro-power generation capacity (in this study the Rio Grande, Mekong, Yangtze and potentially the Okavango) involve planning of major investments over decadal timescales which could potentially be informed by climate change projections. In the most general sense there are a number of changes that may be considered to be relatively robust responses to a warming climate, notably the modification of hydrological regimes associated with reduced snow and ice cover, increased surface evaporation, increased likelihood of hydrological extremes in most places and a general pattern of wet (dry) regions becoming wetter (drier). For some regions these do provide a compelling basis for adaptive response, for example the southwest USA (Seager et al., 2009).

It is equally clear that developing appropriate adaptation activities on the ground in particular localities are constrained by the degree of uncertainty in future projections of river flow in many of the river basins studies reported here. For example, Nobrega et al. (2011) note that the magnitude of water resource changes projected by some GCMs under "moderate" warming scenarios is large enough to affect hydro-power generation capacity, with implications for planning decisions on the necessity and timing of construction of new power plants to ensure future energy supply. Such investments have decadal-scale lead times for which climate change projections are relevant. The major stakeholders in this context are faced with the difficultly of interpreting highly contrasting projections of water resources. We might envisage a number of possible responses in this context. One would be to simply ignore the climate change projections in planning, thereby implicitly accepting the risk of a potentially large shortfall in energy generation capacity. Another would be to conduct a more comprehensive probabilistic assessment of climate change impacts such that the risk profile can be fully quantified and incorporated into investment decision making, along with other projections of energy demand.

Such probabilistic approaches have been developed to quantify distributions of future climate changes, based on "grand ensembles" of multiple GCMs and perturbed physics experiments (e.g. www.climateprediction.net). New et al. (2007) provide an example of application to a hydrological impact study. Methodologies to "weight" ensemble members based on the accuracy of GCM representation of historical climate and/or convergence in projections have also been proposed (e.g. Tebaldi et al, 2005) and subsequently used in climate change assessments (e.g. Shongwe et al., 2009) and indeed for management of Okavango River (Wolski, personal communication, 2009). Probabilistic assessments are attractive as they can provide quantitative "risk" profiles to inform decision making. Indeed the UKCIP 2009 climate projections utilise similar methodologies. However, Stainforth et al. (2007a) provide a cautionary analysis of the applicability of such probabilistic "risk" profiles 
scenarios based on an understanding of the limitations of climate models. In any case, in many regions such approaches are unlikely to circumvent the problem of uncertainty in future projections which results primarily from inter-GCM uncertainty in precipitation processes.

Our results from basins around the world suggest that for water resources projected change is characterised by high uncertainty. Indeed, there is little doubt that the unified methodology used in this present study almost certainly underestimates the magnitude of uncertainty. There are a number of different interpretations of what might be the most appropriate response to this condition of uncertainty. On one hand, we can place an emphasis on the merits of probabilistic assessments of climate risk and optimise decision making accordingly in light of quantified trade-off between cost and risk (e.g. Koutsyannis et al., 2009; Taylor et al., 2009). This may be appropriate in regions with a clear and consistent hydrological response. On the other hand, as argued by Pielke (2009), we can accept that such probabilistic assessments do not really reflect meaningful "likelihoods" of future conditions (as discussed above and in Kundzewicz et al., 2008, 2009). Under this view it becomes more appropriate to use climate projections as potential scenarios around which to devise "no-regrets" responses which are relatively robust to a wide range of future conditions. This demands that in many real life cases we need to devise new decision making and management processes to ensure "robust" responses. In a similar vein, Stainforth et al. (2007b), using hypothetical case studies, outline an analysis "pathway" for decision making in which the probabilistic climate projections simply provide a lower bound on the envelope of "non-discountable" climate change, around which decisions may be structured. Moreover, such a condition whereby we may expect substantial but uncertain climate changes suggests than we should emphasise actions to reduce vulnerability of populations to climate and other stresses as a priority adaptive response to climate change.

We may then consider the prospects for reducing uncertainty projections of hydrologically relevant variables in the foreseeable future. There are some strong reasons for assuming that this is unlikely. First, uncertainty in estimates of climate sensitivity has remained remarkably stable over the last $20 \mathrm{yr}$ or so (Solomon et al., 2007). Second, improvements in the sophistication of Earth System Models whilst necessary is unlikely to reduce uncertainty in the near term as the incorporation of additional components in the climate system can increase rather than decrease uncertainty (e.g. dynamic carbon cycle in C4MIP experiments). Third, the quest for higher resolution estimates for many impact studies requires downscaling of GCM output which, especially in the case of dynamical downscaling, can add further uncertainty to the projection ensemble (e.g. Deque et al., 2005). The findings of the studies in this issue make the clear case that impact studies must utilise results from an ensemble of GCMs and it follows that there is little to be gained from using a single regional model in downscaling studies. Accordingly, the experimental design of the major regional-wide downscaling projects such as PRUDENCE for Europe, NARCCAP for North America and CORDEX whose initial focus will be Africa involves multiple regional models within a grand ensemble. In this context, climate change adaptation activities must learn to accept and embrace considerable uncertainty in future projections of climate impacts in many sectors.

In parallel with the grand ensemble approach to representing uncertainty, however, we should also improve our understanding of the physical basis of projected climate (and hydrological) change, especially at the regional scale. Through analysing climate and hydrological processes over the past and the future it can be possible to diagnose more fully the physical processes driving change and variability and their representation in models, and so provide the basis for constraining the uncertainty envelope.

One further area where there may be potential for fruitful developments is decadal climate prediction. The climate over the next 1-2 decades will be dominated by natural climate variability, substantially controlled through decadal modes of ocean-atmosphere interaction, and the anthropogenic signal. A few studies (e.g. Smith et al., 2007) have indicated that, when initialised with the observed ocean state, climate models can provide some forecast skill over the next decade, at least for large scale temperature anomalies. Whilst the lead time of such forecasts is certainly more in line with most real world decision horizons than climate change timescales, such forecasts remain very much in the experimental domain.

Finally, notwithstanding potential development in climate prediction, it is abundantly clear that changing climate will intersect with other pressures on water resources in many parts of the world in the future and that water resource management must address these issues within an integrated framework.

Acknowledgements. This work was supported by a grant from the UK Natural and Environmental Research Council (NERC), under the Quantifying and Understanding the Earth System (QUEST) programme (Ref. NE/E001890/1). The authors are also greatly indebted to the project partners associated with each of the study river catchment.

Edited by: T. Wagener

\section{References}

Alexander, L. V., Zhang, X., Peterson, T. C., Caesar, J., Gleason, B., Klein Tank, A., Haylock, M., Collins, D., Trewin, B., Rahimzadeh, F., Tagipour, A., Ambenje, P., Kumar, K. Rupa, Revadekar, J., Griffiths, G., Vincent, L., Stephenson, D. B., Burn, J., Aguliar, E., Brunet, M., Taylor, M., New, M., Zhai, P., Rusticucci, M., and Vazquez-Aguirre, J. L.: Global observed changes in daily climate extremes of temperature and precipitation, J. Geophys. Res., 111, D05109, doi:10.1029/2005JD006290, 2006. 
Allen, M. R. and Ingram, W. J.: Constraints on future changes in climate and the hydrologic cycle, Nature, 419, 224-232, 2002.

Arnell, N. W.: Effects of IPCC SRES* emissions scenarios on river runoff: a global perspective, Hydrol. Earth Syst. Sci., 7, 619641, doi:10.5194/hess-7-619-2003, 2003a.

Arnell, N. W.: Relative effects of multi-decadal climatic variability and changes in the mean and variability of climate due to global warming: future streamflows in Britain, J. Hydrol., 270, 195213, 2003b.

Arnell, N. W.: Climate change and global water resources: SRES emissions and socio-economic scenarios, Global Environ. Change, 14, 31-52, 2004a.

Arnell, N. W.: Climate change impacts on river flows in Britain: the UKCIP02 scenarios, J. Chart. Inst. Water E., 18, 112-117, 2004b.

Arnell, N. W.: The relationship between climate forcing and hydrological response in UK catchments, Hydrol. Earth Syst. Sci. Discuss., 7, 7633-7667, doi:10.5194/hessd-7-7633-2010, 2010.

Arnell, N. W., Cannell, M. G. R., Hulme, M., Kovats, R. S., Mitchell, J. F. B., Nicholls, R. J., Parry, M. L., Livermore, M. T. J. and White, A.: The Consequences of $\mathrm{CO}_{2}$ Stabilisation for the Impacts of Climate Change, Clim. Change, 53, 413-446, 2002.

Arnold, J. G., Srinivasan, R., Muttiah, R. S., and Williams, J. R.: Large area hydrologic modeling and assessment part I: model development, J. Amer. Wat. Res. Assoc., 34, 73-89, 1998.

Bates, B. C., Kundzewicz, Z. W., Wu, S. and Palutikof, J. P. (Eds.): Climate Change and Water, Technical Paper of the Intergovernmental Panel for Climate Change, IPCC Secretariat, Geneva, Switzerland, 2008.

Christensen, J. H., Hewitson, B., Busuioc, A., Chen, A., Gao, X., Held, I., Jones, R., Kolli, R. K., Kwon, W.-T., Laprise, R., Magaña Rueda, V., Mearns, L., Menéndez, C. G., Räisänen, J., Rinke, A., Sarr, A., and Whetton, P.: Regional Climate Projections, in: Climate Change 2007: the Physical Science Basis, contribution of Working Group I to the Fourth Assessment Report of the Intergovernmental Panel on Climate Change, edited by: Solomon, S., Qin, D., Manning, M., Chen, Z., Marquis, M., Averyt, K. B., Tignor, M., and Miller, H. L., Cambridge University Press, Cambridge, United Kingdom and New York, NY, USA, 2007.

Collischonn, W., Allasia, D. G., Silva, B. C., and Tucci, C. E. M.: The MGB-IPH model for large-scale rainfall-runoff modelling, Hydrol. Sci. J., 52, 878-895, 2007.

Deque, M., Jones, R. G., Wild, M., Giorgi, F., Christensen, J. H., Hassell, D. C., Vidale, P. L., Rockel, B., Jacob, D., Kjellstrom, E., de Castro, M., Kucharski, F., and van den Hurk, B.: Global high resolution versus limited area model climate change scenarios over Europe: quantifying confidence level from PRUDENCE results, Clim. Dynam., 25, 653-670, 2005.

Gosling, S. N. and Arnell, N. W.: Simulating current global river runoff with a global hydrological model: model revisions, validation and sensitivity analysis, Hydrol. Process., 25, 1129-1145, doi:10.1002/hyp.7727, 2010.

Gosling, S. N., Bretherton, D., Haines, K., and Arnell, N. W.: Global Hydrology Modelling and Uncertainty: running Multiple Ensembles with a campus grid, Philos. T. R. Soc. A, 368, 1-17, 2010.

Gosling, S. N., Taylor, R. G., Arnell, N. W., and Todd, M. C.: A comparative analysis of projected impacts of climate change on river runoff from global and catchment-scale hydrological models, Hydrol. Earth Syst. Sci., 15, 279-294, doi:10.5194/hess-15279-2011, 2011.

Grey, D. and Sadoff, C. W.: Sink or Swim? Water security for growth and development, Water Policy, 9, 545-571, 2007.

Held, I. M. and Soden, B. J.: Robust responses of the hydrological cycle to global warming, J. Climate, 19, 5686-5699, 2006.

Hitz, S. and Smith, J. L.: Estimating global impacts from climate change, Global Environ. Change, 14, 201-218, 2004.

Hughes, D. A., Andersson, L., Wilk, J. and Savenije, H. H. G.: Regional calibration of the Pitman model for the Okavango River, J. Hydrol., 331, 30-42, 2006.

Hughes, D. A., Kingston, D. G., and Todd, M. C.: Uncertainty in water resources availability in the Okavango River Basin as a result of climate change, Hydrol. Earth Syst. Sci. Discuss., 7, 5737-5768, doi:10.5194/hessd-7-5737-2010, 2010.

Kingston, D. G. and Taylor, R. G.: Projected impacts of climate change on groundwater and stormflow in a humid, tropical catchment in the Ugandan Upper Nile Basin, Hydrol. Earth Syst. Sci. Discuss., 7, 1913-1944, doi:10.5194/hessd-7-1913-2010, 2010.

Kite, G. W.: The SLURP model, in: Computer Models of Watershed Hydrology, edoted by: Singh, V. P., Water Resources Publications, Colorado, 521-562, 1995.

Kite, G. W., Dalton, A., and Dion, A.: Simulation of streamflow in a macroscale watershed using general circulation model data, Water Resour. Res., 30, 1547-1559, 1994.

Koutsoyiannis, D., Montanari, A., Lins, H. F., and Cohn, T. A.: Climate, hydrology and freshwater: towards an interactive incorporation of hydrological experience into climate research. Discussion of "The implications of projected climate change for freshwater resources and their management", edited by: Kundzewicz, Z. W., Mata, L. J., Arnell, N., Döll, P., Jiménez, B., Miller, K., Oki, T., Şen, Z., and Shiklomanov, I., Hydrol. Sci. J. 54, 394 405, 2009.

Kundzewicz, Z. W., Mata, L. J., Arnell, N., Döll, P., Jiménez, B., Miller, K., Oki, T., Şen, Z., and Shiklomanov, I.: The implications of projected climate change for freshwater resources and their management, Hydrol. Sci. J., 53(1), 3-10, 2008.

Kundzewicz, Z. W., Mata, L. J., Arnell, N. W., Döll, P., Jimenez, B., Miller, K., Oki, T. and Şen, Z.: Water and climate projections, Reply to "Climate, hydrology and freshwater: towards an interactive incorporation of hydrological experience into climate research", edited by: Koutsoyiannis, D., Montanari, A., Lins, H. F., and Cohn, T. A., Hydrol. Sci. J., 54, 406-415, 2009.

Leemans, R. and Eickhout, B.: Another reason for concern: regional and global impacts on ecosystems for different levels of climate change, Global Environ. Change, 14, 219-228, 2004.

Levy, P. E., Cannell, M. G. R., and Friend, A. D.: Modelling the impact of future changes in climate, $\mathrm{CO}_{2}$ concentration and land use on natural ecosystems and the terrestrial carbon sink, Global Environ. Change, 14, 21-30, 2004.

Mastrandrea, M. D. and Schneider, S. H.: Probabilistic integrated assessment of "dangerous" climate change, Science, 304, 571575, 2004.

Meehl, G. A., Stocker, T. F., Collins, W. D., Friedlingstein, P., Gaye, A. T., Gregory, J. M., Kitoh, A., Knutti, R., Murphy, J. M., Noda, A., Raper, S. C. B., Watterson, I. G., Weaver A. J., and Zhao, Z.-C.: Global Climate Projections, in: Climate Change 2007: The Physical Science Basis, Contribution of Working Group I 
to the Fourth Assessment Report of the Intergovernmental Panel on Climate Change, edited by: Solomon, S., Qin, D., Manning, M., Chen, Z., Marquis, M., Averyt, K. B., Tignor, M., and Miller, H. L., Cambridge University Press, Cambridge, United Kingdom and New York, NY, USA, 2007.

Milly, P. C. D., Dunne, K. A., and Vecchia, A. V.: Global pattern of trends in streamflow and water availability in a changing climate, Nature, 438, 347-350, 2005.

Mitchell, T. D.: Pattern scaling - an examination of the accuracy of the technique for describing future climates, Clim. Change, 60, 217-242, 2003.

Mitchell, T. and Jones, P.: An improved method of constructing a database of monthly climate observations and associated highresolution grids, Int. J. Climatol., 25, 693-712, 2005.

New, M., Hulme, M., and Jones, P. D.: Representing twentieth century space-time climate variability, Part 2: development of 19011996 monthly grids of terrestrial surface climate, J. Climate 13, 2217-2238, 2000.

New, M., Lopez, A., Dessai, S., and Wilby, R.: Challenges in using probabilistic climate change information for impact assessments: an example from the water sector, Phil. Trans. Roy. Soc. A, 365, 2117-2131, 2007.

Nicholls, R. J.: Coastal flooding and wetland loss in the 21 st century: changes under the SRES climate and socio-economic scenarios, Global Environ. Change, 14, 69-86, 2004.

Nóbrega, M. T., Collischonn, W., Tucci, C. E. M., and Paz, A. R.: Uncertainty in climate change impacts on water resources in the Rio Grande Basin, Brazil, Hydrol. Earth Syst. Sci., 15, 585-595, doi:10.5194/hess-15-585-2011, 2011.

Osborn T. J.: A user guide for ClimGen: a flexible tool for generating monthly climate data sets and scenarios, Climatic Research Unit, University of East Anglia, Norwich, 17 pp., 2009.

Pielke: Gewex News, available at: http://www.gewex.org/gewex nwsltr.html, 19, 2, 2009.

Parry, M. L., Rosenzweig, C., Iglesias, A., Livermore, M. and Fischer, G.: Effects of climate change on global food production under SRES emissions and socio-economic scenarios, Global Environ. Change, 14, 53-67, 2004.

Schröter, D., Cramer, W., Leemans, R., Prentice, I. C., Araújo, M. B., Arnell, N. W., Bondeau, A., Bugmann, H., Carter, T. R., Gracia, C. A., de la Vega-Leinert, A. C., Erhard, M., Ewert, F., Glendining, M., House, J. I., Kankaanpää, S., Klein, R. J. T., Lavorel, S., Lindner, M., Metzger, M. J., Meyer, J., Mitchell, T. D., Reginster, I., Rounsevell, M., Sabaté, S., Sitch, S., Smith, B., Smith, J., Smith, P., Sykes, M. T., Thonicke, K., Thuiller, W., Tuck, G., Zaehle, S., and Zierl, B.: Ecosystem Service Supply and Vulnerability to Global Change in Europe, Science, 310, 1333-1337, 2005.

Seager, R., Tzanova, A., and Nakamura, J.: Drought in the Southeastern United States: Causes, Variability over the Last Millennium, and the Potential for Future Hydroclimate Change, J. Climate, 22(19), 5021-5045, 2009.

Shongwe, M. E., Van Oldenborgh, G.-J., Van Den Hurk, J. J. M.: Projected Changes in Mean and Extreme Precipitation in Africa under Global Warming, Part I: Southern Africa, J. Climate, 22, 3819-3837, 2009.

Smith, D. M., Cusack, S., Colman, A. W., Folland, C. K., Harris, G. R., and Murphy, J. M.: Improved surface temperature prediction for the coming decade from a global climate model, Science,
317, 796-799, 2007.

Solomon, S., Qin, D., Manning, M., Chen, Z., Marquis, M., Averyt, K. B., Tignor, M., and Miller, H. L. (Eds.): Contribution of Working Group I to the Fourth Assessment Report of the Intergovernmental Panel on Climate Change, Cambridge University Press, Cambridge, United Kingdom and New York, NY, USA, 2007.

Stainforth, D. A., Allen, M. R., Tredger, E. R., and Smith, L. A.: Confidence, uncertainty and decision-support relevance in climate predictions, Phil. Trans. R. Soc. A, 365, 2145-2161, 2007a.

Stainforth, D. A., Downing, T. E., Washington, R., Lopez, A. and New, M.: Issues in the interpretation of climate model ensembles to inform decisions, Phil. Trans. R. Soc. A, 365, 2163-2177, 2007b.

Taylor, R. G.: Rethinking water scarcity: role of storage, EOS, Trans. Am. Geophys. U., 90(28), 237-238, 2009.

Taylor, R. G., Koussis, A., and Tindimugaya, C.: Groundwater and climate in Africa: a review, Hydrol. Sci. J., 54, 655-664, 2009.

Tebaldi, C., Smith, R. L., Nychka, D., andMearns, L. O.: Quantifying uncertainty in projections of regional climate change: a Bayesian approach to the analysis of multimodel ensembles, J. Clim., 18, 1524-1540, 2005.

Thorne, R.: Uncertainty in the impacts of projected climate change on the hydrology of a subarctic environment: Liard River Basin, Hydrol. Earth Syst. Sci. Discuss., 7, 3129-3157, doi:10.5194/hessd-7-3129-2010, 2010.

Tol, R. S. J.: The Benefits of Greenhouse Gas Emission Reduction: An Application of FUND, FNU-64, Hamburg University and Centre for Marine and Atmospheric Science, Hamburg, 2005.

Toth, F. L., Bruckner, T., Fussel, H. M., Leimbach, M., and Petschel-Held, G.: Integrated assessment of long-term climate policies: part 2 - Model results and uncertainty analysis, Clim. Change, 56, 57-72, 2003.

Trenberth, K. E., Jones, P. D., Ambenje, P., Bojariu, R., Easterling, D., Klein Tank, A., Parker, D., Rahimzadeh, F., Renwick, J. A., Rusticucci, M., Soden, B., and Zhai, P.: Observations: Surface and Atmospheric Climate Change, in: Climate Change 2007: The Physical Science Basis, Contribution of Working Group I to the Fourth Assessment Report of the Intergovernmental Panel on Climate Change, edited by: Solomon, S., Qin, D., Manning, M., Chen, Z., Marquis, M., Averyt, K. B., Tignor, M., and Miller, H. L., Cambridge University Press, Cambridge, United Kingdom and New York, NY, USA, 2007.

Van Lieshout, M., Kovats, R. S., Livermore, M. T. J., and Martens, P.: Climate change and malaria: analysis of the SRES climate and socio-economic scenarios, Global Environ. Change, 14, 8799, 2004.

Warren, R.: Impacts of global climate change at different annual mean global temperature increases, in: Avoiding Dangerous Climate Change, edited by: Schellnhuber, H. J., Cramer, W., Nakicenovic, N., Wigley T. M. L., and Yohe, G., Cambridge University Press, Cambridge, 93-131, 2006.

$\mathrm{Xu}, \mathrm{H}$., Taylor, R. G., and Xu, Y.: Quantifying uncertainty in the impacts of climate change on river discharge in sub-catchments of the Yangtze and Yellow River Basins, China, Hydrol. Earth Syst. Sci., 15, 333-344, doi:10.5194/hess-15-333-2011, 2011. 